\title{
清酒の香気について
}

山 本

香気より清酒香気つ本体を解明しょうとしたものであ る。

まず，清酒中の香気成分つ検索は，大正の終り鈴木梅 太郎博士によって合成酒が始为て世に問われて以来, 多 くの研究が行なわれ山田 ${ }^{1)}$, 庄司 ${ }^{2)}$, 東 ${ }^{3)}$, 平4) 等が清酒 めるい性粄焼酎等から分離, 同定した香気成分の数 も，その存在が推定されたもの含めて 50 種に近い多 数に上っている。しかし，これらの諸成分によって清酒 香気の本体が解明されたといえない事は，これらを合成 酒等に添加して香気を検した結果 ${ }^{5}$ かからも明らかで, こ のたるに東等3) はとの存在が推定される約 400 種に上る 化合物を合成して香気を検する方法をとったが，清酒香 気つ本体については依然不明であった。

しかし, これらの諸研究の結果, 清酒の香気が単純な 幾つかの香気成分によるるのでなく, 予想外に多くの成 分が寄与する複合的な香気である事を明らかにする事が 出来た。この様な構成成分解明つ行詰りは, 清酒香気つ 本体が何に由来するのか学，そつ前駆物質から明らかて しょうとする研究を促したといえる。

清酒の原料つ総べてが米と水で方る事を思うと，香気 生成つ前駆物質は当然米の中つ成分に求められるべき で, 守随, 坂本 ${ }^{6)}$ は米を澱粉, 脂質, 蛋白質の 3 区分に 分ち，各々を醱醳させて生成物つ香気を検した結果，清 酒香気の主たるるのが米中の蛋白質が分解され，醱酵さ れて生ずる事を明らかにし，さらにすすんで，蛋白質を 構成する各種アミノ酸についてる，同様に添加酘酵試験 の結果, ロイシン, バリン, フェニルアラニン等を添加 したものが，特に優れた香気を附与し得た事を述べてい る。しかし，この様に香気発生つ前駆物質が明らかにな っても, 清酒香気の本体については依然として不明であ った。

眽って, 従来の諸研究を顧みると, 蒸溜法, 抽出法等 によった香気成分の捕集の手段に問題があるのに気がつ く。すなわち, 清酒中の大量のエタノール, 糖質, 蛋白 
質等の存在定考慮すると，共沸混合物の生成㐫るいは抽 出能率の低下は免れる事が出来ず，また，実験室で行な 万際の試料の処理能力に引限界が岕って, 特微量成分 については完全汇分別, 捕集し得たとはいい難い。

筆者はこれを補う方法として，メルカプタン類化特別 な親和性を示す化学活性樹脂の一つであるハイドロキノ ンーホルマリン樹脂(以下 $\mathrm{Hq}-\mathrm{F}$ 樹脂と略す)の構造特性 に基づいた撰択吸着性と，予め香味液（合成酒添加用醸 造酒）の精製に使用した活性炭を熱エタノールで抽出， 再活性化した再生活性炭の有する非撰択吸着性江着目し て, 新しい吸着法によって清酒中の香気成分の略々全量 を能率良く捕集する事に成功した ${ }^{7)}$ 。この様な吸着法に よって捕集した香成分は，吸着前後の香気拉よび減圧蒸 溜液の紫外部吸収の変化, 捕集香気成分による復元試験 の結果から，元の清酒中の略々全量である事は確実であ る。をた, 醸造後 14 か月を経た古酒約 $1 \mathrm{k} l$ より吸着法 によって捕集した香気成分の分離と同定汇よって，従来 全く知られていない 16 種に就よぶ微量の香気成分の存 在を明らかにし ${ }^{8)}$, 同時にそれらの収量から, 元の清酒 中に叔ける濃度の大要を知る事が出来た。これらの結果 を第 1 表倸す。また，この他沈すすで知られている 諸種の香気成分の存在を明らかにし得たが，分別過程に 括ける收量から、それらの間の存在比の大要を知る事が 出来穴。

\section{3. 微量成分の果す役割り}

従来の研究で明らかになった諎種の香気成分を合成酒 等に配合, 添加した結果, 期待した清酒様の香気を附与 する事は出来ず, 却って附け香, 薬品臭等つ不自然な感

第 1 表 吸着捕集物中の新香気成分

I. $\mathrm{Hq}-\mathrm{F}$ 樹脂捕集物

1. 焦性葡萄酸エチル

2. $\alpha$-ケト $n$-酪酸エチル

3. $\alpha$ ーケトイソ吉草酸エチル

4. $\alpha$ ーケトイソカプロソ酸エチル

5. ベンッアルデヒド

6. フェニルアセトアルデヒド

7. p-オキシベンッアルデヒド

8. p-オキシ桂皮酸

9. フェニル酢酸エチル

10. $p$-オキシ安息香酸およびそのニステル

II. 再生活性炭捕集物

11. $\alpha$ ーオキシイソカプロン酸エチル

12. 乳酸エチル

13. 桂皮アルデヒド

14. ヴァニリン

15. $\beta$ ーフェニルェチルアルコール酶酸エステル

16. ヴァニリン酸

17. フェルラ酸
を免れる事が出来なかった。このために，切角有為な諸 研究の結果が，実際汇合成酒等の品質の向上に利用出来 なかったのでめるが，これらの理由については，天然物 の中沫未知の微量成分が存在して自然な感を附与寸る のに重要な因子になっているとか, 使用した添加香気成 分中の微量の不純物が荻いしているのであるう等種々論 議されたが，山く亲で推定の域を出なかった。

\section{（1）自然な感を附与する因子}

第 2 節に述べた吸着捕集物の中，再生活性炭によって 捕集した高沸点中性区分，すなわち，吸着活性炭の熱工 タノール抽出液を減圧下にエタノールを溜去し, 残渣を エーテルで抽出, 抽出エーテル液を $10 \%$ 炭酸リーダ, $5 \%$ 菏性ソーダ， $5 \%$ 塩酸と振って酸性，弱酸性，塩基 性の諸成分を除去した中性区分を，さらに $25 \%$ 重亚硫 酸ソーダと振って混在するカルボニル化合物を分った 後, エーテルを溜去し, 残渣を減圧蒸溜注よって 5 つの 区分汾画した。

この中, b. p. $75^{\circ} \mathrm{C} / 2 \mathrm{~mm}$ の溜分は比較的収量も多 く, $\beta$ フエニルエチルアルコール様の香気学有し, 合成 酒に $1 \mathrm{mg} / l$ 添加すると, 何等自然な感を害う事なく香, 味共汇顕著な品質の向上が見られる。この区分をガスク トマトグラフィー（G.C. と略す）で検した結果, 主要 な 1 ピークの他に, 幾つかの小ピークが存在して, 主要 な 1 成分に幾つかの微量の成分が混在している事を知っ た。ついで，同区分を $5 \%$ 苛性ソーダ液と共に封管中で 加熱した後，中性区分をとって同様に G.C. で検する と, 前と混在した小ピークは何れも完全消失して, こ れらが何れもエステルである事が分った。票た，加水分 解で得た主要成分である中性成分はフェニルウレタンに 導いて融点, 元素分析, 混融試験を行なった結果, すで に東 ${ }^{3)}$ によってその存在が報告されている $\beta$-フェニル エチルアルコールである事が確実化証明できた。また， 同区分を G.C. で検すると，完全な 1 ピークを認める

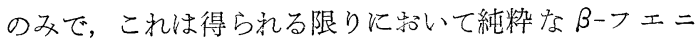
ルエチルアルコールである事は確かで岕るが，これを前 と同様に $1 \mathrm{mg} / l$ 合成酒汇添加して検すると, 今度は同 アルコール特有の青味臭, 白粉臭が附与されて明らかに 不自然である。

この事は, 得られる限り純粋なるのを用いても附け香 等の不自然感を免れる事が出来ない事を意味すると共 飞, 加水分解前汇存在した微量つエステル類が, 同区分の 自然感の附与飞重要な因子となっていた事を物語るもの

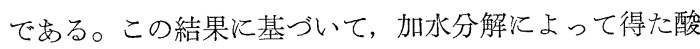
区分を検した結果, 乳酸, 吉草酸, 酢酸つ他に $\alpha$-オキ シイソカプロン酸 (ロイシン酸)が存在する事を知り，ま た，G.C. そよって 
エステルの他は何れるエチルエステルとして存在する事 を知った。この中でもロイシン酸エチルは醸造物中にそ の存在を始めて明らかになし得た新しい香気成分である が，各種の香気成分に微量添加してその効果を験した結 果, 特に顕著な自然感附与の作用を有する事を知り, 従 来未知成分が清酒の中で自然感の附与に重要な因子々な っていると考兄られていた事を裏附けると共に，その本 体の一つを明らかになし得たのである。

\section{(2) 吟醸香について}

$\mathrm{Hq}-\mathrm{F}$ 樹脂により吸着, 捕集した揮発性成分は減圧蒸 溜によって $9 つ の$ 画分に分けたが，この中 b. p. $\sim 100^{\circ} \mathrm{C}$ $/ 20 \mathrm{~mm}$ の区分は顕著な芳香を有し，合成酒に $2 \sim 3 \mathrm{mg} / l$ 添加すると自然な感を害う事なく，梨香に類したいわゆ る吟醸香を附与する。同区分を G.C. で検した結果，予 想外に多くの成分よりなる事を知ったが，芳香成分は加 水分解によって酸区分に移ると共に，年の芳香を著しく 減じる。また，2.4-ヂニトロフエニルヒドラジン試薬の 滴加により, 著量の鮮黄色のヒドラゾン結晶を析出し, その芳香を完全に消失する。これらの事から，同区分の 芳香成分はケト酸のエステルと推定され, 加水分解によ って得た酸区分の検索によって, 焦性葡萄酸, $\alpha$-ケトー $n$-酪酸, $\alpha$-ヶトイソ吉草酸, $\alpha$-ケトイソカプロン酸の 存在を同定できた。また，G.C. によって，これらの各 ケト酸が何れも元の清酒中では土チルエステルとして存 在する事を明らかにする事ができたと共に，中でも $\alpha$ ケトイソカプロン酸, 焦性葡萄酸のエチルエステルが最 も多量に存在する事を知った。この中, 焦性葡萄酸エチ ルを除いて他の 分として始めて見出したものであるが，これらは極めて 芳香に富み, 清酒香気の中でも最も重要な因子となって いる事は容易に推定できる。

つぎに, この中でも最も多量に存在し, しかも著しい 芳香を有する $\alpha$ ケトイソカプロン酸エチルの香り効果 を験するために，合成酒に $0.5 \sim 1 \mathrm{mg} / l$ 添加すると，何 等自然感を害う事なく, 顕著な清酒棦感を附与するが, さらにその量を增して $1.5 \mathrm{mg} / \mathrm{l}$ 添加すると, 梨香とい われるいわゆる吟醉香を呈するに到る。

この事は，従来特殊な成分に由来すると考兄られて来 た吟醉香が，普遍的な香気成分の量的な因子に過ざない 事を示するので，実際に各種銘柄の醸造酒について $\alpha$ ケト酸エステル類の定量を行なった結果, 分析に供した 8 点の清酒並びに香味液の何れも, 前に検出した各種の ムーケト酸エステル類が存在し, 特に吟醸酒には普酒の $2 \sim 3$ 倍量も存在して, 前に得た結果を裏附敄る事が出 来た。

\section{（3）その他の香気成分}

清酒を浴温 $55^{\circ} \mathrm{C}$ 以下, $1 \mathrm{~mm}$ 減圧下で蒸溜し，その約 $2 / 3$ 量をドライアイスで冷却, 捕集した溜液は主要な芳 香を全く失う事なく, 元の清酒の香りをほとんど保持す る。この溜液に炭酸りーダを加兄て前と同様に蒸溜し， ついで重亜硫酸ソーダ, 最後に苛性ソーダを加えて加 熱, 還流した後蒸溜液を得た。この操作で元の清酒様の 芳香を持った溜液から揮発性の遊離酸, カルボニル化合 物, エステル成分を除いた各段階で香りの変化を検する 事が出来たが，この中，カルボニル化合物拉よびェステ ル成分を除去した時に最も顕著な変化が認められ，特に カルボニル化合物学除去すると, 華やかな香気の大部分 が失われる。この様少カルボニル化合物として, 吸着捕 集物の中よりベンッアルデヒド，フェニルアセトアルデ ヒド，桂皮アルデヒド，ヴアニリンの存在を同定でき た。

また，この他に清酒中の徽香を附与する成分としてフ エニル酶酸エチル, 酒粕様の香気に関与するカプリル酸 エチルの存在を明らかにしたが，次章に述べる清酒香気 の生成の機作から推して, まだ多くの香気成分の存在が 推定されるもので, これらの解明は今後に残された問題 である。

\section{4. 清酒香気の生成の機作}

アルコール䤑酵に際して副生するフーゼル油が，イソ アミルアルコール等の高級アルコール類を主とするるの でめり，それが原料中の蛋白質の分解，醱酵によって生 ずる事を明らかにしたのは，今世紀初頭に物ける NEUBERG 一派の業績であり，ここに始めて酽造物の香気成 分と，その生成の因果関係が確立され，さらにアミノ酸 の生体内あるい醱酵代謝の解明に発展し，現在の多彩 な生化学の一つの基礎となったのである。同様に清酒の 香気成分とその前駆物質の間の变化の機作が明らかにな れば，その本体を解明する上で，をた醸造過程に和ける 酸酵の機作を埕 ら上で最も有力な手段となり得る事は容 易に考它られる。

（1）KREBS の酸化型のアミノ酸代謝式に従った 香気成分

清酒の香気の主たるるのが米の中の蛋白質に由来する 事が明らかにされ, 一方, 蛋白質の分解, 酸酵, すなお ち, 構成アミノ酸の一般代謝については KREBS ${ }^{(9)}$ によ りその経路が解明された。これを(4.1) 式に示す。

上式に赫いて実線で示した矢印は，すでにその経路が 証明されたもの，また，点線の矢印は生成物が証明され て，その経路が推定されるものである。

いま，米の蛋白質の中でも最も多量に見出されるロイ 


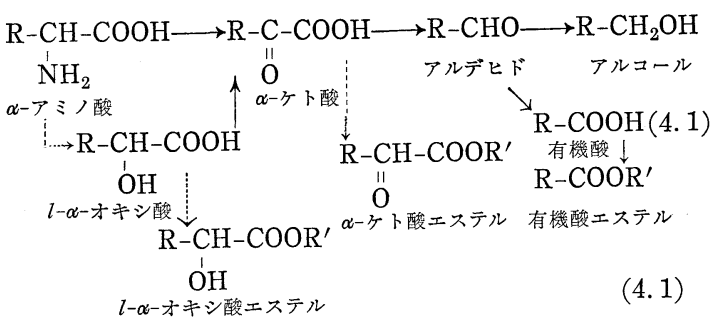

シン $\left(\begin{array}{c}l_{-}{ }_{\mathrm{CH}_{3}}^{\mathrm{CH}_{3}} \\ \mathrm{CHCH}_{2} \mathrm{CH}-\mathrm{COOH} \\ \mathrm{NH}_{2}\end{array}\right)$ を例として,

式と，これまでに得られた清酒香気成分の知見を対比す ると,イッアミルアルコール( $\left(\begin{array}{l}\mathrm{CH}_{3} \\ \mathrm{CH}_{3}\end{array}>\mathrm{CHCH}_{2} \mathrm{CH}_{2} \mathrm{OH}\right)$, 吉草酸 $\left(\begin{array}{l}\mathrm{CH}_{3} \\ \mathrm{CH}_{3}\end{array}>\mathrm{CHCH}_{2} \mathrm{COOH}\right)$ 特よびそのエステル $\left(\begin{array}{l}\mathrm{CH}_{3} \\ \mathrm{CH}_{3}\end{array}>\mathrm{CHCH}_{2} \mathrm{COOR}\right)$, イソバレロアルデヒド $\left(\begin{array}{l}\mathrm{CH}_{3} \\ \mathrm{CH}_{2}\end{array}\right\rangle$ $\left.\mathrm{CHCH}_{2} \mathrm{CHO}\right)$ は既飞知られて和り，ロイシン酸エチル

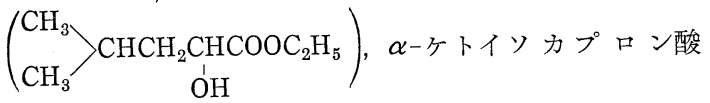
エチル( $\left(\begin{array}{l}\mathrm{CH}_{3} \\ \mathrm{CH}_{3}\end{array}>\mathrm{CHCH}_{2} \mathrm{COCOOC}_{2} \mathrm{H}_{5}\right)$ そついてはすでに述 ベた如くで，いずれるロイシンの代謝生産物である。す なわち，清酒香気の主たるるのがアミノ酸の KREBS の 代謝図式に従った代謝生成物の綜合的な香気であり, 特 に代謝中間生成物の一部がェステルとして香気の生成に 重要な因子となっている事を知った。

\section{（2）チロシンの醱醰代謝生産物}

清酒成分の中には，明らかにアミノ酸から生成したも ので，乙かもKREBS 式洼わない微量成分も存在する。 チロシンに由来するものとして, チトゾールの存在は早 くから知られて居り ${ }^{10)}$, 特有の苦味と低い香気を与光て いる。京た, 筆者の研究で $p$-オキシ桂皮酸, オキシベ ンシアルデヒド，P-オキシ安息香酸趽よびそのエステル 存在が明らになり, これらが何れもチロシンの醱酵代謝 で生成する事を知った ${ }^{11) 。 ~}$

この結果, チロシンの醱酵代謝には KREBS 式に従う ものと, 全く異なった䣨酵代謝によるるのが在存する事 が分った。しかも，代謝最終生成物と考光られる $p$-オ キシ安息香酸の一部がェステルとして存在する事は，こ の様な変化の最終過程まで酵母生体内で進行した事を物
語るもので，そのエステル生成能と共に興味深い知見と 考学られるか，これらについては目下との解明に努めて いる。

また，この様な新しい代謝経路が単にチロシンに限ら れるものかも問題がある。すなわち，前節に述べた桂皮 アルデヒド， ベンッアルデヒドの存在はフエニルアラニ ンについても，一般式に従わない代謝経路の存在を意味 するもので，他のアミノ酸に招いても，同様汇新しい醊 酵代謝の経路が存在するならば，当然香気の生成化重要 な因子となるもので，今後の研究の進展が期待される分 野である。

この他に清酒成分として新たに見出されたフェルラ 酸，バニリン酸，バニリン等のグアヤシル系化合物の存 在は，アミノ酸以外の前駆物質による香気成分さ生成の 機作を考慮する必要を示し，また，カプリル酸エチル等の 高級脂肪酸扣よびそのエステルの生成については, 酵母 による糖代謝として，これるで明らかにされていない代 謝経路を推定しなければならないが，これらについて詳 述するには紙数が限られて就り，別の機会に僙りたい。

\section{5. 総括}

以上, 清酒の香気について, 従来の研究並びに新しい 香気成分の捕集の方法を述べ，それによって明らかにな った幾つかの微量成分の香り効果から清酒香気の構成の 一端を覗い，また，それらの生成の機作について得られ た新しい知見を記述した。しかし，これで清酒香気の本 体が解明されたものではない。むしろ，問題の所在が明 らかになり, 清酒香気の種々のからくりが解きほぐされ るのは今後に期待すべきもので, もしこの拙文によっ て, 読者の中から, 新たにこの方面の研究に意欲を燃や される方が出るならば，筆者の望外の幸である。

\section{引用 文 献}

1) 山田正一：本誌，23，(4) 18，(5) 26，（6） 24 (1928）；農化, 4. 544 (1928); Bull. Agr. Chem. Soc. J., 4, 83 (1928)

2) 庄司謙次郎：理研報, 11, 1353 (1932); ibid., 15, 230 (1936)

3) 東 恒人：J.S.R., 33, 727 (1936) ; 合酒技報, 11, 70 (1955)

4) 平 友恒 : 菝化, 3, 1312 (1927); ibid. 6, 413 (1930)

5) 飯田茂次 : 本誌, 54, 543 (1959)

6) 守随稀雪, 坂本政義他: 合酒技報, 6, 1 (1950); ibid. 10,69 (1951); ibid, 13，1 (1952); 酸協誌，18，121 (1960)

7) 山本 淳: Agr. and Biol. Chem., 25, 744 (1961)

8) 山本 渞: 農化, 35 ' $616,619,711,715,819,823,1082$ (1961)；合酒技報， 20，916（昭 35) - ibid. 26，6（昭 36）

9) H.A.KREBS : Biochem. J., 29, 1620 (1935)

10）高橋, 阿部: 東宸学報, p. 512 (1913)

11) 山本 淳, 大森大陸 : 農化誌に投稿予定 